EXEMPLARIa Classica

Journal of Classical Philology

19, 2015, pp. 149-153

ISSN 1699-3225

\title{
NOTES TO A RECENT EDITION OF PINDAR'S OLYMPIAN ODES
}

Michel Briand, Pindare. Olympiques. Texte ètabli par A. Puech, Paris: Les Belles Lettres, 2014, 326 pp. ISBN 987-22-5124-001-5

I was impressed with Briand's perceptiveness in this edition. For example, he observes that odes need not be performed either wholly by a chorus or wholly by a soloist, as discussed below. Similarly, he notes that the crowning of the altar at the end of Olympian 9 need not have anything to do with a literal crown (p.138). And he introduces fundamental concepts well. The translations are generally correct, as are the commentaries. Furthermore, I like that Briand has constructed his commentaries in paragraphs rather than in lemmata. This makes the commentaries more readable, particularly for Briand's intended audience of non-specialists. Overall, the book is a success.

Briand begins his introduction with the proem of Olympian 1, using it as an example of how Pindar's odes are intertwined with complex moral, aesthetic, and political concerns. Having touched on the complexity of Pindar's odes, Briand writes a brief history of Pindar's reception, showing how Pindar's complexity has won Pindar both favor and disregard. This section should be of interest to the general reader, who will quickly realize what an important and contentious position Pindar has had in literary and intellectual history. Briand writes this section well.

Thereafter, Briand turns to Pindar's poetry and its context. Having introduced the Pindaric corpus and the Olympic games, he shows that he has his finger on the pulse of contemporary epinician criticism, by treating in turn the importance of Olympia's geography in the odes, the importance of deixis in the odes, the importance of understanding epinician odes not as texts but as performances, and the importance of the question of unity in the odes. Briand closes this section by addressing the terms 'lyric' and 'melic' and by discussing some points of Pindaric style. This is all well done, and these sections will be helpful to the reader coming to epinician poetry for the first time.

But Briand also introduces some positions with which I disagree. First, Briand considers it likely that some Pindaric odes were first performed at Panhellenic sanctuaries (xv, xxix, 150). I have argued against this position 
elsewhere. ${ }^{1}$ Second, Briand thinks that the epinician kômos was a 'cortège festif,' (xviii, xxxii, and passim). I have argued against this interpretation also. ${ }^{2}$ I will not repeat my position on the epinician kômos here, but I will

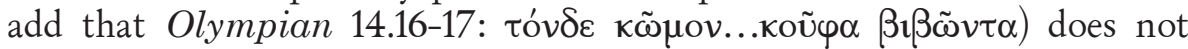
provide evidence in favor of the suggestion that the epinician kômos is a group of revelers. We are dealing with the personification of an inanimate phenomenon in this phrase. Let us consider, for the sake of comparison, the statement 'the meter is running.' To conclude from this statement that 'the meter' is a living organism that has legs would be to misunderstand the use of metaphor in the phrase. ${ }^{3}$ We have misunderstood analogous metaphor at Olympian 14.16-17.

Briand also introduces the solo vs. choral debate (xviii), which developed around the performance context of epinician poetry, and he insightfully notes that we need not assume that all epinician odes were performed by a soloist or that all epinician odes were performed by a chorus. Briand does not provide evidence for this suggestion, but I would like to make a few comments here in support of it because I have recently come to the same conclusion. It seems to me that the solo vs. choral debate was so contentious because each group was half right and half wrong. There are passages in the odes that make good sense when we understand them to have been performed by a soloist and there are passages in the odes that make good sense when we understand them to have been performed by a chorus; and there is no reason to assume that some passages of an ode could not have been performed by a soloist while other passages of the same ode would have been performed by a chorus. We need not assume, then, that passages that seem to express the opinion of a single person, say Pindar, would have been voiced by a chorus (as the choral-hypothesis assumes) or that passages that seem to express the voice of a choral body would have been performed by a soloist (as the solohypothesis assumes). It seems to me that Pindar was a soloist dialoguing with his chorus in multiple odes. Scholars have regularly found the narrator's voice in epinician poetry to be particularly complex and/or confusing, but it now seems to me that much of the discourse on complexity and confusion that arises in discussion of the epinician narrator's voice derives from unsound implicit assumptions regarding the nature of performance for epinician odes.

There is further reason to hypothesize that some of Pindar's odes were dialogic. For example, archaic and classical poetic genres offer reason to hy pothesize that epinician odes could have been dialogic(with solo-performers in dialogue with choral-performers), since some archaic and classical poetic

1 "Was Epinician Poetry Performed at Panhellenic Sanctuaries?," GRBS 52, 2012, 338-60.

2 "The kômos of Pindar and Bacchylides and the Semantics of Celebration," CQ 60, 2010, $302-12$.

${ }^{3}$ For discussion of such metaphorical personification, see Z. Kövekses, Metaphor: A Practical Introduction (Oxford, 2010) 55-56, with reference to further bibliography. 
genres were dialogic in this manner (one thinks of drama, for example). We should not be surprised that we do not find changes of performer marked in the manuscripts of Pindar, since it was common practice not to mark change of performer in Greek poetic texts. Taking a relevant example, I note that the Bacchylides papyrus does not provide notation to mark change of performers for B. 18, but scholars infer that B. 18 was performed as a dialogue between a soloist and a chorus. We may infer that it was no more important to keep record of the manner of first performance of an ode (i.e. how it may have been broken up between soloist and chorus) than it was to keep record of an ode's choreography. Accordingly, knowledge of the manner of first performance for particular odes seems to have been lost rather quickly. Our new model of epinician performance, then, should look something like this: some odes may have been performed by a soloist; some odes may have been performed by a chorus; and some odes may have been performed by a soloist and a chorus in dialogue. The soloist seems to have regularly provided musical accompaniment either for himself as soloist, or for the chorus, or for both. This is not the place to discuss these topics at greater length.

In the next section of the introduction, Briand turns to the historical Pindar. Briand offers 'the facts' about Pindar, as provided by scholia, vitae, etc. The particularly interesting part of this section is Briand's discussion of the circular reasoning that some critics (who received 'the facts' from the odes and then used these 'facts' to interpret the odes) have employed in an attempt to position the odes in a historical context. Briand is similarly insightful when he discusses the manner in which fanciful stories passed as biography in antiquity: you know the one about the bees that built a honeycomb in Pindar's mouth, don't you?

There is more to go in this introduction. First, Briand discusses the organization of the Olympian odes in relation to the historical competitions as well as in relation to the patrons who commissioned them. This is fine. Second, Briand turns to Pindaric meter. This section is unsatisfactory, since Briand does not provide enough explanation for the reader to begin to scan Pindar's odes. In comparison, Herwig Maehler, in his student's edition of some poems by Bacchylides (Bacchylides: A Selection (Cambridge, 2004)), provides enough metrical discussion so that his readers can begin scanning Bacchylides' poems and thereby begin getting a feel for their rhythms (we note that Maehler's volume is intended for a similar audience to that of Briand). Thereafter, Briand introduces important terms in epinician poetry (e.g. aretá, phuá). This is fine, except for Briand's discussion of kharis. As Gregory Nagy has observed, kharis means compensation in epinician poetry. ${ }^{4}$ And, as I have further observed, the term refers specifically to the compensation,

${ }^{4}$ Pindar's Homer: The Lyric Possession of an Epic Past, Baltimore, 1990, 65-6. 
i.e. the counter-gift, within the system of reciprocity. ${ }^{5}$ In epinician poetry, then, kharis is not 'très polysémique' (xxxi). The introduction closes with a list of passages in which Briand's edition differs from that of Puech and with some notes on Briand's method of translation. Excepting the description of meter and the description of kharis, these largely descriptive introductory sections will be helpful for the book's intended audience.

Thereafter, the book contains translations and commentaries, followed by three appendices. I shall provide comments on individual odes below. In the first appendix, Briand shows how Pindar's odes can be grouped in various manners: by the region whence the laudandus; by competition won; by date of the ode; by metrical criteria; and by mythographical criteria. Considering the odes from these various perspectives may offer the reader insights that the traditional grouping does not offer. In the second appendix, Briand provides an overview to the biographical traditions that developed around Pindar's life, property, presumed religious character, and presumed political inclinations, and to the sources that preserve these traditions. This is a sound and helpful overview. In the third appendix, Briand provides a rich introduction to Pindaric reception, from Plato to Heidegger, and concludes by providing references to modern and contemporary scholarship on Pindar.

I note here some interpretative disagreements on individual odes:

\section{Olympian 1}

Line 8: I do not believe that Briand is correct to assert (p. 14) that ho polyphatos hymnos refers, not to a single ode, but to the whole epinician genre. As Stein notes (cited in D. Gerber's commentary on Olympian 1), ho has deictic force in the phrase ho polyphatos hymnos; 'this highlywrought hymn' refers to Olympian 1. Like other scholars, Briand translates polyphatos as 'très fameux.' But, given that the phrase is used in reference to Olympian 1, which cannot be très fameux at the time of its first performance (since the ode has not yet been performed), it is most likely that Pindar etymologizes the adjective from huphaino (cf. R. Renehan, "Conscious Ambiguities in Pindar and Bacchylides," GRBS, 19 (1969) 217-228, at 220). Pindar comments here on the labor that he has put into composing the ode, referring to it as 'highly-wrought.'

Lines 16-17: Briand infers that Olympian 1 is 'une ode symposiale' (p. 15) from Pindar's reference to men regularly playing at symposia. This inference is unsound since Pindar's reference to repetitive symposiastic behavior need not have anything to do with the performance of Olympian 1.

5 "Xópıs in the Epinician Odes of Pindar and Bacchylides," given at the Society for Classical Studies, Annual Meeting 2015, New Orleans, LA [https://classicalstudies.org/annual meeting /146/abstract/ $\chi \alpha \dot{\rho}$ ıৎ-epinician-odes-pindar-and-bacchylides] 
Lines 17-20: Like other translators, Briand translates in such a way that we misunderstand kharis in this passage. The Greek means: "well, come, take the Dorian lyre from the peg, if compensation/requital for Pisa and for Pherenikos has placed your mind under very sweet considerations." Pisas and Pherenikou are objective genitives. The if-clause is rhetorical, and such 'if clauses' are common in prayers. For example, at the beginning of the Iliad (lines 37-42), Chryses asks A pollo to hear his prayer, if Chryses has ever roofed over a temple or if he has ever offered fat thigh pieces of bulls or goats to Apollo. Chryses would not make such statements unless he had roofed over a temple to Apollo and offered fat thigh pieces of bulls and goats to Apollo. Similarly, there is no doubt that the epinician poet will requite Hieron in response to Hieron's accomplishment at Pisa with Pherenikos (in fact, the poet is already doing so, since the ode is being performed at the time that the phrase is enunciated). The passage has been misunderstood regularly because the denotation of kharis in epinician poetry has been misunderstood regularly.

Line 30: Like others, Briand capitalizes kharis and translates kharis as a divinity, Grâce. I do not think that this is correct. Pindar here uses kharis, requital/compensation, as a metaphor for poetry. It is requited poetry (e.g. epinician poetry) that makes things that are sweet for mortals when that poetry brings them honor (i.e. during performance). Epinician poetry, however, can be deceptive, hence the following gnome: "the days to come are the wisest witnesses." People will see, in the days to come, whether what a poet said about a laudandus, in a specific kharis (i.e. in a specific ode), was true. Pindar makes the same argument with another gnome at Olympian 4.17-18. Accordingly, we should not capitalize kharis in this passage.

Lines 75-76: Here is another problem in translating kharis. The Greek means: "Come, Poseidon. If the dear gifts of Kupria find their telos in requital, hold the bronze spear of Oinomaos." Again, the 'if-clause' is rhetorical: Pelops knows that Poseidon understands the system of reciprocity and, accordingly, that Poseidon knows that the gifts (dōra) of Aphrodite (i.e. sex) should find their fulfillment in a counter-gift, kharis. Since Pelops has given Poseidon sex, Poseidon is now obligated to 'fulfill' (hence telletai) the requisite requital. This is a good example of how kharis works within the system of reciprocity: gifts, dōra, find their telos in counter gift(s), kharis.

Briand infers that Pindar did not receive a commission for Hieron's chariot victory of 468 (p.23). This is an unsound inference. That our corpus of Pindaric epinician odes does not include an epinician ode for this victory does not allow us to conclude that Pindar did not receive a commission to celebrate that victory.

Olympian 2

Lines 8-9: Pindar asserts that the Emmenidai, having toiled greatly, 
hold Akragas. Shortly thereafter, Pindar says that allotted time brought kharis and wealth upon the Emmenidai's native aretai. Aretá means 'accomplishment' more often than 'virtue' in Pindar's odes, and it is best to translate aretá here as accomplishment. Pindar, then, says that allotted time brought wealth and requital upon the Emmenidai's 'familial' (cf. LSJ s.v. gnesios) 'accomplishments.' In this passage, Pindar includes the martial accomplishments that won the Emmenidai ploutos and martial kharis (e.g. the requital that was allotted to the Emmenidai by the gods on behalf of the labor they undertook to attain Akragas) and the athletic accomplishments that win them epinician kharis. This Pindaric ode is a kharis, requital, offered in compensation for Theron's Panhellenic victory.

\section{Olympian 3}

Line 6: Briand's supposition that the epinician kômos is a 'cortège festif' is problematic, as noted above (so too Briand on the performance of Olympian 9, p. 139).

Line 24: aliou should be uppercased. There is no sound reason to deanimate Helios in this passage. ${ }^{6}$

\section{Olympian 4}

Briand finds the ending of the ode surprising, since, after the myth of Erginos, Pindar does not turn to gnomic material, to metapoetic material, or to victor praise. But I suggest here that the ode's myth should be read not only in relation to Psaumis's victory but also in relation to the structure of Olympian 4. In the myth, Erginos' swiftness is praised, and Olympian 4 is short and, accordingly, swift. Pindar has constructed the myth as he has, then, not only because it praises the ability of one to prove his worth when tested (which Psaumis surely will do) but also because it can be read metapoetically in praise of swiftness. Pindar's ode, then, contains the metapoetic element that Briand finds lacking in the ode.

\section{Olympian 5}

Line 10: There is a typo in Briand's Greek. The text reads aei dei where it should read aeidei. Briand translates the verb aeidei, however, and he translates it as 'il chante,' as do other scholars. I think that this is incorrect. I suggest that aeidei is more likely causative, as is ekaruke at line 8 in this ode. We should translate aeidei, then, as 'he has sung' rather than as 'he sings.' The laudandus, Psaumis, has the sanctuary, the river, and the lake sung because they are being sung, with the enunciation of aeidei, during the performance of this ode.

${ }^{6}$ See C. Eckerman, "The Landscape and Heritage of Pindar's Olympia," Classical World $107,2013,3-33,20-5$. 


\section{Olympian 6}

Line 5: Like other scholars, Briand suggests that the word sunoikistēr means 'fondateur.' Actually, most scholars translate the word as 'cofounder'/'fellow-founder', given the noun's prefix.7 The word has caused scholars difficulty because Hagesias was not a founder or a co-founder of Syracuse. I suggest here that the word may have caused scholars difficulty because we may not have understood its semantics previously. I suggest that the noun may mean 'the one who participates in the process of colonization.' This need not mean the same thing as 'colonist' and it would not mean 'founder' or 'co-founder' of the colony. It would mean that Hagesias participates in aiding Hieron in Hieron's colonial projects (e.g. the foundation of Aetna). Morphological parallels, including the one extant comparandum (Lykophr. Alex. 964; therewith, see Hornblower Lykophron: Alexandria (Oxford, 2015) 360), favor the interpretation. With the word sunoikister, then, Pindar would celebrate the prestigious connection that Hagesias has with Hieron (as he does elsewhere in this ode), and the word would also flatter Hieron (as Pindar does elsewhere in the ode), since the word would position Hagesias relative to Hieron. Accordingly, the word need not mean that Hagesias was a founder/co-founder, and the comparandum from Lykophron, cited above, corroborates this (cf. Adorjáni, op. cit.). In fact, the context of the comporandum from Lykophron suggests that it is unlikely that sunoikister means co-founder. Thus, there is good textual reason to consider other possible denotations for sunoikistēr. Moreover, Pindar's intended audience would know that Hagesias was neither founder nor co-founder of Syracuse; accordingly, they would not be inclined to interpret the noun thus. They would know, however, of Hagesias' close connection to Hieron, and this may encourage them to make sense of the unusual word as I have outlined here. The phrase 'sunoikistêr of famous Syracuse' may be analogous to the phrase 'vice president of the United States,' with the genitive 'of famous Syracuse' describing the geographical realm in which Hagesias has the prestigious position of being the one who aids Hieron in colonization. Furthermore, we should consider the possibility that 'of famous Syracuse' may be a metonymy for 'of the famous Syracusans.'

Line 27: Pindar uses the metapoetic phrase 'gates of song' (Briand: 'portes des hymnes'), and Briand assumes that the imagery is chosen in reference to the 'portique' at the beginning of the ode. I do not think that this is correct. In this strophe, Pindar develops imagery from mule-cart racing at Olympia, the competition that Pindar's patron, Hagesias, is celebrated for winning in

\footnotetext{
${ }^{7}$ See most recently, with reference to further bibliography, Z. Adorjáni, Pindars sechste olympische Siegesode: Text, Einleitung und Kommentar, Leiden 2014) 126, Z. Stamatopoulou, "Inscribing Performances in Pindar's Olympian 6," TAPA 144, 2-14, 1-17, 7, and M. Foster, "Hagesias as Suoikistêr: Seercraft and Colonial Ideology in Pindar's Sixth Olympian Ode," CA 32, 2013, 283-321.
} 
this ode. Accordingly, I suggest that Pindar throws open the 'gates of song,' near the beginning of his song, just as the starting gates were opened on the hippodrome at the beginning of equestrian competitions. Pindar, then, develops his metapoetic imagery here from the realia of the contest that his patron won, as he does in other odes. ${ }^{8}$

\section{Olympian 7}

Line 11: Like other scholars, Briand capitalizes and thereby divinizes kharis here. But kharis here is used as a metaphor for an ode, performed in accompaniment with phorminx and auloi (12). Accordingly, we should not capitalize kharis here. The verb 'oversees' has caused scholars confusion, since we have not recognized Pindar's metaphorical use of personification in this passage. The verb does not assure us that a divinity is referenced here anymore than a phrase such as 'hostility oversees their business meeting' would necessitate that we deduce that hostility is a divinity. On this trope, see my note above on the epinician kômos and my note below on atrekeia in $O .10$.

Line 14: like many scholars, Briand infers that Rhodes is the spouse of Helios. But Pindar only says that Rhodes is the 'nymph' of Helios. It is unsound to deduce from this that Rhodes is Helios' wife.'

The gnome at lines 43-4 has regularly caused commentators trouble. I suggest that it means "reverence/respect for forelearning casts accomplishment (aretá) and kharmata for men." As noted above, aretá regularly means accomplishment in epinician poetry, as it does here. The gnome is introduced in light of the immediately preceding mythic section and in light of the immediately following mythic section. In the mythic materials, Helios wanted his children to offer sacrifice to Athena first, but they did not. We learn that Helios gave the Rhodians the 'forelearning' wherewith they might have had 'accomplishment' (aretá) of their task and concomitant kharmata, but they did not have aretá and kharmata because a cloud of forgetfulness came upon them (45). One is reminded of the saying: prior proper planning prevents poor performance. The Rhodians had poor performance because possible prior proper planning was taken away by a cloud of forgetfulness. Accordingly, their forgetfulness shows that they did not have 'aidos' for forelearning. The passage has caused commentators difficulty previously because they have chosen, regularly, to render aretá with excellence and have interpreted promatheos as 'foresight' (i.e. something that comes from within) rather than as forelearning (i.e. something that comes from

\footnotetext{
${ }^{8}$ For discussion of this metaphor and for Catullus' productive reworking of it, see C. Eckerman, "Muses, Metaphor, and Metapoetics in Catullus 61," HSCP , 108 forthcoming.

${ }^{9}$ For discussion, see C. Eckerman, "Ancient Greek Literature and the Environment: A Case Study with Pindar's Olympian 7," in A Global History of Literature and the Environment, ed. Louise Westling and John Parham (Cambridge, forthcoming).
} 
an external agent). The role of Helios in the myth, however, clarifies how we should interpret promatheos, since Helios is the external agent who provided the Heliadai with the forelearning that should have allowed them to accomplish their task. The myth and the argument of the contiguous gnome reinforce one another (for the promath-root used as suggested here, see too Olympian 8. 60). Briand mistranslates this passage by translating aretá as 'excellence' and by translating promatheos as 'Prometheus' (p.97).

Briand (pp. 102, 106) incorrectly asserts that this ode was inscribed on the temple of Athena at Lindos. ${ }^{10}$

\section{Olympian 8}

Briand (118) suggests that the opening prayer to Olympia may suggest that this ode was first performed at Olympia. This is an unsound inference. ${ }^{11}$

Line 57 and 80: For reasons noted above, I do not think that Briand is correct to translate kharis as grâce in these passages.

\section{Olympian 9}

Line 11: 'hurl a sweet winged arrow at Pytho.' This need not mean that Epharmostos won at Delphi previously. One could interpret the phrase as expressing hope for victory at Delphi in the future.

Line 113: nothing in the text encourages us to assume that a procession was associated with the performance of this ode.

\section{Olympian 10}

Line 12: For reasons noted above, I do not think that 'amicale gratitude' is an appropriate translation of philan kharin.

We may be incorrect to uppercase 'atrekeia' in this passage. When Pindar says that 'strictness holds sway' over the city of the Western Lokrians, strictness need not be a divinity anymore than 'strictness' would need to be a divinity in the phrase: strictness holds sway over dealings at the Farmers Market. As noted above, there are passages in Pindar's odes in which Pindar's use of metaphorical personification has encouraged us to read personages into the odes where we should not. 'Atrekeia' may be another example of this.

Line 77: again, Briand introduces a cortège into the performance of this ode, but the text does not support Briand's inference.

\section{Olympian 14}

Briand asserts that " $L$ ' epinicie est une procession festive, qui se dirige vers le sanctuaire des Grâces" (191). He cites no evidence in favor of this assertion,

\footnotetext{
${ }^{10}$ For discussion, see C. Eckerman, "Ancient Greek Literature and the Environment: A Case Study with Pindar's Olympian 7” (op. cit.).

${ }^{11}$ Cf. W. Race, Pindar. Olympian Odes. Pythian Odes, Cambridge, MA 1997, 134.
} 
202 Chris Eckerman: Notes to a Recent edition of Pindar’s Olympian Odes

and I am not aware that there is any evidence in favor of hypothesizing such a performance scenario. Moreover, nothing in the ode allows us to assert that the ode 'se dirige vers le sanctuaire des Grâces.'

CHRIS ECKERMAN

University of Oregon eckerman@uoregon.edu 